\title{
Vilko Ukmar in sodobni koncepti glasbenega zgodovinopisja
}

Vilko Ukmar (1905-1991) je širši javnosti veliko bolj znan po skladateljskem opusu kot pa po svojem univerzitetnem pedagoškem delu in glasbenem zgodovinopisju. V svojem dolgem življenju je segal na najrazličnejša področja, na katerih se je izkazal kot veliki poznavalec estetsko-filozofskih vprašanj in prodoren pisec o umetnosti, še posebno o glasbeni misli in estetiki ter slogu. Njegovo krčevito iskanje življenjskega smisla in pomena umetnosti na splošno, ne le glasbene, se je enakovredno izražalo v njegovih publikacijah in obsežnem glasbenem opusu. Po začetnem študiju prava se je kmalu odločil, da bo prav glasba njegova življenjska sopotnica, in ji je posvetil tako rekoč ves svoj čas. Ukmarjevi dosežki in nesebično umetniško prizadevanje pričajo o izjemni ustvarjalnosti, vrelcu misli, ki je izviral bodisi iz njegovega glasbenega opusa bodisi je bilo tesno povezano z njim.

Ukmarjevo publicistično delo je nastajalo ne le za potrebe takratnega šolstva, ampak tudi z mislijo po zapolnitvi vrzeli v pomanjkanju domače literature o svetovni glasbeni zgodovini. Tako upravičeno pravimo, da je avtor prvega in do zdaj edinega izvirnega slovenskega dela te vrste - to je njegova knjiga Zgodovina glasbe (1948). Oblikovana je tako, da si zgodovinski dogodki sledijo v nepretrganem časovnem zaporedju, razpira pa tudi zanimive povezave med likovno in glasbeno umetnostjo. Knjiga pomeni vrhunec njegovega zgodovinopisno-publicističnega dela, s katerim se je ukvarjal že v prvem obdobju poučevanja na konservatoriju v Ljubljani. V tistem obdobju je nastala skripta Pogled na zgodovinski razvoj glasbene umetnosti (1937), ki jo lahko označimo za predhodnico Zgodovine glasbe, saj imata veliko skupnih točk. Glasba v preteklih dobah (1955) in Glasba v preteklosti (1975) - oba dela pomenita logično nadaljevanje prejšnjih dveh publikacij. Gre za isto knjigo, druga je ponatis prve s spremenjenim naslovom. Za obe je značilna izčiščena in zgoščena snov, ki postreže s temeljnimi faktografskimi podatki. Do zdaj omenjene publikacije so imele poleg pedagoškega pomena tudi izrazito znanstveno-estetski vidik, ki v domači literaturi še vedno ni presežen. Izrazito pedagoško usmerjena sta priročnika Razvoj glasbe in glasbene oblike ter Uvod v umevanje glasbene umetnosti, ki sta nastala za potrebe tedanjih učnih načrtov za glasbeni pouk v višjih razredih osnovne šole oziroma v gimnazijah. Poleg zgodovine glasbe, s katero se je najprej ukvarjal, je v poznejših letih prišel v ospredje glasbeni slog z estetiko. Izsledke in preučevanje s tega področja glasbene publicistike lahko beremo v izdajah Po lepoti k resnici (1972) in Poglavja iz estetike glasbe (2007), v katerih se je izkazal za izjemnega poznavalca umetnosti na splošno. 
Pri raziskavi Ukmarjevega publicističnega dela je bilo ključno ugotoviti, kateri avtorji so nanj najbolj vplivali oziroma pri kom se je zgledoval. Tega posredno v knjigah ni mogoče zaslediti, saj ne navaja sprotnih opomb - to je analizo njegovega dela nekoliko otežilo. Izsledki so kljub temu zanimivi, saj je mogoče poleg Ukmarjevega lastnega slogovno-jezikovnega razvoja opazovati tudi povezavo z drugimi avtorji. Ukmar je, kljub temu, da je prevzel precej misli od vodilnih piscev svojega časa, vedno ohranjal svoj slog in misli. To se kaže tudi v nadgrajevanju in dopolnjevanju gradiva ter v poglobljenih mislih, iz katerih vejejo apoliničnost in dionizičnost, človeški duhovni in duhovno-slogovni razvoj, pa tudi močna navezanost na naravo, človeka in njegove umetnine. Red, lepota in ne nazadnje estetika so bile glavne smernice ne le njegovih misli, ampak celotnega ustvarjalnega dela.

Na Ukmarjeve slogovno-estetske poglede na »družbeni razvoj« V zvezi s slogovnim razvojem je prek Izidorja Cankarja vplival Max Dvořák. Njegov pojem »umetnostne zgodovine kot eksaktne zgodovinske discipline«, ki izhaja iz sloga, je treba razumeti v smislu razvoja duha. Prav Cankar je v slovenski umetnostni zgodovini uveljavil Dvořákovo Kunstgeschichte als Geistesgeschichte, ki jo je Ukmar uspešno nadaljeval na glasbenem področju. Pri tem ga je vodilo načelo, da pri razlagi zgodovine ne bo uporabljal dejstev, ki jih je mogoče najti v knjigah in priročnikih, marveč spoznanje človeškega duha v posameznih zgodovinskih obdobjih. V tem je bil nadaljevalec poti, ki jo je začrtal že Guido Adler, osnove pa je postavila dunajska umetnostnozgodovinska šola.

Omenjeni so imeli na Ukmarja največji vpliv, vsak na svojem področju, vendar nikoli ne v celoti. Po Adlerju je povzel besedilo za svoje publikacije, po Dvořáku in Cankarju umetnostnozgodovinsko razčlenjevanje obdobij, vendar je jasno, da si je pri omenjenih sicer »sposodil« osnovo, toda nadgradil jo je s svojimi idejami in mislimi.

Ukmar je svoje misli nadgrajeval in dopolnjeval, a človek in njegove umetnine so bile vedno v središču njegovega zanimanja. Kot vsej umetnosti je tudi glasbi izhodišče in cilj lepota. In ta lepota je bila Ukmarjeva spremljevalka vse življenje in mu je poleg glasbe pomenila pojem in smisel življenja. To se zelo lepo kaže v njegovih publikacijah, ki so vedno zgledno ter jasno in natančno oblikovane. V njih išče človeško resnico in njeno apoteozo ob pomoči umetnosti in družbenega razvoja, ki vedno teži k izboljšanju. Glasba je bila za Ukmarja vse. Bila je tesno povezana z njegovim bistvom in smislom življenja ter razvojem - ne le njegovim, ampak človeškim na splošno, s katerim sta si delila razvojno pot.

Obranjeno 14. junija 2016 na Filozofski fakulteti Univerze v Ljubljani. 